\title{
Comb-like PEG-containing polymeric composition as low toxic drug nanocarrier
}

\author{
Lesya Kobylinska ${ }^{*} \mathbb{0}$, Igor Patereha², Natalia Finiuk ${ }^{3}$, Natalia Mitina ${ }^{4}$, Anna Riabtseva ${ }^{4}$ Igor Kotsyumbas², \\ Rostyslav Stoika ${ }^{3}$, Alexander Zaichenko ${ }^{4}$ and Sandor G. Vari ${ }^{5}$
}

*Correspondence:
lesya8@gmail.com
1 Danylo Halytsky Lviv
National Medical University,
Pekarska str., 69a, Lviv 79010,
Ukraine
Full list of author information
is available at the end of the
article

article

\begin{abstract}
Background: Development of biocompatible multifunctional polymeric drug carriers is crucial in modern pharmaceutics aimed to create "smart" drugs. The high potential of the PEGylated comb-like polymeric nanocarrier (PNC) in delivering both traditional and experimental drugs to tumor cells in vitro and in vivo has been demonstrated previously. In the present study, we investigated the general toxicity of polyethylene glycol (PEG) processed with both covalent and non-covalent attachments of PEG to compose a comb-like polymer that behaves like a simple chain of $\mathrm{n}$ monomers decorated with swollen side chains. The PNC possesses properties of a water-soluble surfactant containing methyl-terminated PEG side branches in some monomer units attached covalently to the carbon chain backbone.
\end{abstract}

Results: We have demonstrated that the synthesized PNC possesses weak toxic effects toward human leukemia cells (HL-60 and Jurkat lines), as well as toward hepatocellular (HepG2), colon (HCT116) and breast (MCF-7) tumor cell lines. Additionally, after a long period (20 days) of intraperitoneal administration, the PNC had no significant toxic effects in laboratory white mice $(470 \mathrm{mg} / \mathrm{kg}$ body mass in $1 \mathrm{ml})$ and Wistar rats (440 $\mathrm{mg} / \mathrm{kg}$ body mass in $10 \mathrm{ml}$ ).

Conclusion: The developed PNC we studied can be qualified as a compound of grade 4 toxicity (low toxicity substance). The reduced toxicity of this PNC in combination with its improved bioavailability and previously detected capability to enhance cytotoxicity toward tumor cells in vitro and potential tumor treatment effects in vivo suggests its potential as a safe drug delivery platform for treating various diseases, especially cancer.

Keywords: Drug delivery system, Polyethylene glycol, Polymeric nanocarrier, Toxicity, Rats, Mice

\section{Introduction}

In the last two decades, lipid and polymer-based nanocarriers have been studied as alternative drug delivery systems that can enhance the solubility of drugs by encapsulating existing and new anticancer drugs (Feng et al. 2015; Zhang et al. 2009). Nanocarriers provide additional advantages for tumor treatment since the conjugate of the anticancer drug with different carriers may reduce systemic toxicity and enhance drug accumulation in malignant tissue (Feng et al. 2015; Zhang et al. 2009). In these ways, nanocarrierbased drug delivery will improve the efficacy of anticancer chemotherapy (Wang et al. 2017).

(c) The Author(s) 2018. This article is distributed under the terms of the Creative Commons Attribution 4.0 International License (http://creativecommons.org/licenses/by/4.0/), which permits unrestricted use, distribution, and reproduction in any medium, provided you give appropriate credit to the original author(s) and the source, provide a link to the Creative Commons license, and indicate if changes were made. 
In modern pharmacology, polymeric nanocarriers (PNCs) are the most promising drug delivery platforms for anticancer drugs (Han et al. 2018). PNCs have specific physicochemical properties that should be considered during drug delivery (e.g., molecular weight and size, solubility, density, specific gravity, $\mathrm{pH}$, dissociation) to enhance biocompatibility and biodegradability, and with additional functionalization make drug delivery more effective (Han et al. 2018; Heffeter et al. 2013; Riabtseva et al. 2012; Nath Roy et al. 2017; Li et al. 2003; Zhang et al. 2009).

In the evolution of modern biopharmaceuticals, some of the main tasks are to develop safe nanosized carriers that have low toxicity, physical stability in blood, compatibility with metabolites of the organism, also controlled impact on cells' damage, and the potential to improve targeted delivery of anticancer drugs to tumors (Nath Roy et al. 2017; Igarashi 2008; Zhang et al. 2009; Senkiv et al. 2014). Polyethylene glycol (PEG) is a non-ionic compound that is often used for this purpose (Heffeter et al. 2013; Riabtseva et al. 2012; Nath Roy et al. 2017). Studies have shown that the conjugation of antitumor drugs with a PNC reduced the toxicity and improved the pharmacokinetic parameters of the drugs and increased their therapeutic efficacy (Heffeter et al. 2013; Igarashi 2008). Polymer-based therapeutics has been established as an innovative and dependable method, since the PNC can conjugate with a wide variety of molecules and compounds (e.g., proteins, enzymes, nanoparticles, liposomes, low molecular weight drugs) (Wang et al. 2017).

PEG has been studied comprehensively as a drug carrier because it is soluble in both organic and hydrophilic solvents. Unlike many other synthetic polymers, PEG is relatively hydrophilic. Conjugation with PEG increases the solubility of hydrophobic drugs and prolongs the circulation time in the organism. PEG also minimizes the nonspecific absorption of the drug, provides specific affinity toward the targeted tumor, and increases the drug accumulation in malignant tissue (Heffeter et al. 2013; Riabtseva et al. 2012; Nath Roy et al. 2017). PEG can be conjugated to other polymers to make them less hydrophobic (i.e., PEGylation). The changes in surface hydrophilicity prevent protein adsorption, thereby enabling cell adhesion and proliferation on biomaterial scaffolds (Bunker 2012; Feng et al. 2015). PEG availability in a PNC is a valuable characteristic that makes possible the formation of micelles to make an aggregate of molecules in a colloidal solution, thus containing the hydrophobic compound (e.g., 4-thiazolidinone derivative) and creating a hydrophilic environment for drug delivery in the living organism (Bunker 2012; Feng et al. 2015; Heffeter et al. 2013).

However, the toxicological aspects of using polymeric carriers in pharmacy and medicine remain poorly understood (Faqi 2013, 2017; Bobo et al. 2016). Changes in the attached PEG molecules will modify the shape and size of nanoparticles and alter the toxicity of the PNCs. Such changes will influence the metabolism in research animals (Pinto Reis et al. 2006). The biosafety of novel drugs immobilized on various carriers is uncertain and limits their use in medical practice (Bobo et al. 2016). Therefore, defining the biosafety of different drug delivery systems, particularly their toxicity, is an important stage in the development of new therapeutics.

Previously, high efficiency of using PNCs has been demonstrated for delivery of doxorubicin (Senkiv et al. 2014), ruthenium-containing antitumor preparation KP-1019 (Heffeter et al. 2013), and experimental anticancer 4-thiazolidinone derivatives (Kobylinska 
et al. 2015, 2016) to inhibit growth and survival of tumor cells in vitro and in tumorbearing laboratory mice. The main goal of the present study was to estimate the indicators of general toxicity of the applied PNC in laboratory animals (rats and mice).

\section{Materials and methods}

As shown in Fig. 1, PNC is a water-soluble comb-like polymer of poly(VEP-co-GMA)graft-mPEG consisting of a backbone copolymer of 5-(tert-butylperoxy)-5-methylhex-1en-3-yne (VEP, denoted by "l") and glycidyl methacrylate (GMA, denoted by "m"), and grafted side PEG chains (PEG denoted by "n”) (Riabtseva et al. 2012).

\section{Synthesis and characteristics of PNC}

The synthesis of the PNC was carried out as described previously (Heffeter et al. 2013; Riabtseva et al. 2012; Senkiv et al. 2014). The composition of the PNC was calculated from the results of elemental analysis and analysis of functional groups (Steyermark 1961; Voronov et al. 1996).

The PNC water solution was prepared as follows: $0.093 \mathrm{~g}$ of PNC was dissolved in $0.9 \mathrm{ml}$ DMSO and this solution was added to $8.5 \mathrm{ml}$ of saline solution $(0.9 \%$ aqueous $\mathrm{NaCl}$ solution). Then, the solution was stirred for $1 \mathrm{~h}$ and sonicated for $20 \mathrm{~s}$, $[\mathrm{PNC}]=9.9 \mathrm{mg} / \mathrm{ml}$.

Transmission electron microscopy (TEM) and scanning electron microscopy (SEM) studies of the morphology of the micelles: a transmission electron microscope JEM$200 \mathrm{~A}$ (JEOL, Japan) was used at an accelerating voltage of $200 \mathrm{kV}$. The samples were prepared via polymer dissolution in water, as described above. Samples were prepared by spraying tested solution on a substrate using the ultrasonic dispersant UZDN-1A (Ukrrospribor Ltd, Ukraine) that produces a uniform coating on the substrates. A thin amorphous carbon film deposited on a copper grid was used as a substrate. The dispersant options used were a type UZDN-1 possessing power of $50 \mathrm{~W}$ and frequency of $35 \mathrm{kHz}$. A Zeiss Supra 40/40VP scanning electron microscope (Carl Zeiss Group, Germany) was also used in this study.

The size of polymer micelles was measured by dynamic light scattering (DLS) using a Zetasizer Nano ZS instrument (Malvern Instruments GmbH, Stuttgart, Germany) and by photon correlation spectra, using the NIBS (Non-Invasive Back Scatter) technology at $25{ }^{\circ} \mathrm{C}$. The samples for DLS measurements were prepared by dissolution of polymers

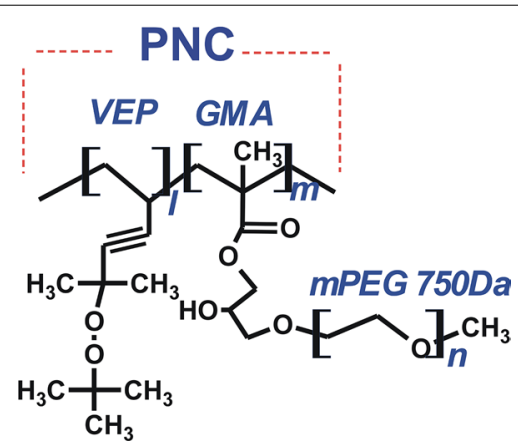

Fig. 1 General structure of the polymeric nanocarrier (PNC): "l," $m$ ", and " $n$ " indicate the number of structural components of the PNC listed in Table 1 
in bidistilled water, $\mathrm{pH} 6.5-7.0$, and the copolymer concentration was $1 \cdot 10^{-2}-5 \cdot 10^{-2} \mathrm{~g} /$ $\mathrm{ml}$. Three to five measurements were made for every sample (each measurement consisted of five cycles, the range between measurements was $5 \mathrm{~min}$ ). For temperaturedependent DLS studies, the solution was allowed to equilibrate for at least $1 \mathrm{~h}$ prior to data collection. Zeta potential experiments were carried out with a Zetasizer Nano Particle (Malvern Instruments GmbH, Stuttgart, Germany) at a fixed temperature of $25^{\circ} \mathrm{C}$. The distributions of the hydrodynamic diameter of PNC at different temperatures were conducted on the Nano Particle Analyzer SZ-100 (HORIBA, Ltd., Kyoto, Japan) and the measurements show a dependence of hydrodynamic diameter of PNC on temperature.

\section{Cytotoxicity in in vitro MTT assay}

Human myeloid leukemia HL-60, human hepatocarcinoma HepG2 cells, and human colon carcinoma HCT116 cells were used from the Institute of Cancer Research at Vienna Medical University (Vienna, Austria). Human breast adenocarcinoma MCF-7 and human $\mathrm{T}$ cell leukemia Jurkat cells were obtained from the Institute of Experimental Pathology, Oncology and Radiobiology (Kyiv, Ukraine). Cells were grown in RPMI1640 culture medium (APP, Austria) or Dulbecco's modified Eagle's medium (DMEM, Sigma-Aldrich, USA) supplemented with $10 \%$ fetal bovine serum (Biowest, France) at the standard conditions.

The cytotoxicity was measured using colorimetric MTT assay (EZ4U, Biomedica, Austria) for assessing cell functional activity after treatment with the PNC. Cells were plated at 5000 cells/well (substrate-dependent cells) or 15,000 cells/well (suspension cells) in $100 \mu \mathrm{l}$ in 96-well plates and allowed to incubate overnight. PNC (equivalent to the amount of polymer in complex with the anticancer drug) was added in $100 \mu \mathrm{l}$ of culture medium and the cells were incubated for $72 \mathrm{~h}$. Afterward, MTT assay was performed according to the manufacturer's recommendations (EZ4U, Biomedica, Austria). Briefly, $20 \mu \mathrm{l}$ of dye solution was added to $200 \mu \mathrm{l}$ of cell culture and incubated for the next $1-4 \mathrm{~h}$ at $37^{\circ} \mathrm{C}$. The optical density was measured with the Absorbance Reader BioTek ELx800 (BioTek Instruments, Inc., USA) at $490 \mathrm{~nm}$ with $630 \mathrm{~nm}$ as a reference.

\section{Trypan blue exclusion test}

Cells were plated at 50,000 cells/well (substrate-dependent cells) or 500,000 cells/well (suspension cells) in $1 \mathrm{ml}$ in 24-well plates and allowed to incubate overnight. PNC at different concentrations was added to the cell culture and incubated for the next $72 \mathrm{~h}$. The cell number was counted in a hemocytometric Neubauer chamber after staining with Trypan blue dye (DV-T10282, Invitrogen, Life Technologies Corporation) at 0.04\% final concentration. The percentage of live cells related to control was calculated as the cell number experiment/cell number control $\times 100 \%$.

\section{Data analyses}

The results of MTT and Trypan blue assays are presented as the mean (M) \pm standard deviation (SD) of three replications. The data were analyzed and illustrated using GraphPad Prism 6 software (GraphPad Software, La Jolla, CA, USA). 


\section{Evaluation of PNC toxicity in vivo}

All animal studies were conducted according to the European Convention on Protection of Vertebrate Animals (Strasbourg, 1986) and corresponding Law of Ukraine (N944, 14.12.2009). The protocols of this study and experimental procedures were approved by the Ethical Committee at Lviv National Medical University (N2, 16.02.2015). The experiments were carried out on white laboratory mice 3-4 months old with body weight of 18-24 $\mathrm{g}$ and white Wistar rats 3-4 months old with body weight of $143-255 \mathrm{~g}$. The PNC was injected daily into the peritoneal cavity. In total, 36 rats and 36 mice were used in the study. Mice were injected with the PNC at doses of 0.1, 0.3, 0.5, and $1.0 \mathrm{ml}$; in rats, the doses were 1.0, 3.0, 5.0, and $10.0 \mathrm{ml}$. The highest dose of the PNC was repeatedly administered to six rats $(10.0 \mathrm{ml})$ and six mice $(1.0 \mathrm{ml}) .1 \mathrm{ml}$ of the solution contained $9.9 \mathrm{mg}$ of the PNC. We could not further increase the amount of applied substance because of the critical volume used for injection. Control groups of rats and mice were injected with a physiological solution of the same volume. To avoid application of too large volume of the diluted substance $(20 \mathrm{~mL} / \mathrm{kg}$ of body weight of laboratory rats), we injected the liquid in two steps during $30 \mathrm{~min}$ (Diehl et al. 2001).

Weighing of experimental animals was carried out after 5, 8, and 14 days. After administration of the PNC, laboratory animals were monitored for 14 days. The following indicators were considered: appearance, uniqueness of animal behavior, intensity and character of motor activity, assessment of food and water consumption, mass of animals, condition of fur and visible mucous membranes, respiration rate, time of occurrence and nature and severity of intoxication, as well as the time of death of the animals or their recovery (Faqi 2013, 2017).

The animals (rats) were euthanized by decapitation while under thiopental anesthesia on the 20th day. Blood was collected and used to obtain serum for determination of the activities of alkaline phosphatase (ALP; 3.1.3.1), $\alpha$-amylase (3.2.1.1), $\gamma$-glutamyltransferase (GGT; 2.3.2.2), lactate dehydrogenase (LDH; 1.1.1.27), alanine transaminase (ALT; 2.6.1.2), aspartate transaminase (AST; 2.6.1.1), and creatine phosphokinase (2.7.3.2). The concentrations of total protein, glucose, urea, creatinine, and of calcium, iron, sodium and chloride ions were also measured. These parameters were measured with standard kits for an automated biochemistry analyzer (Humalyzer 3000, Germany).

Daily urine and feces were collected from treated rats, dried, and examined using thinlayer chromatography on a Sorbfil plate (Russian Federation) in acetone-dioxan (4:1) solvent mixture. The chromatographic plates were developed with iodine vapor, and pure VEP, GMA, and PEG were used as controls for the presence of specific compounds.

The results were established by colorimetric assay using the Absorbance Reader (BioTek Instruments, Inc., Winooski, VT, USA). Data analysis was performed with GraphPad Prism 6 software (GraphPad Software). Statistical analysis of the in vivo results was done using variance (MS Excel software; Microsoft Corp., Redmond, WA, USA) and Student's $t$ test. The difference was considered statistically significant and marked with stars for: * $P \leq 0.05$. 
Table 1 Composition, molecular weight, and colloidal chemical characteristics of the PNC

\begin{tabular}{|c|c|c|c|c|c|c|c|}
\hline \multicolumn{3}{|c|}{ Composition of PNC, \% } & \multirow{2}{*}{$\begin{array}{l}\text { PNC molar } \\
\text { weight, } \mathrm{kDa}\end{array}$} & \multicolumn{4}{|c|}{ Characteristics of micelle-like structures } \\
\hline $\operatorname{VEP}(l)$ & GMA $(m)$ & PEG $(n)$ & & $\begin{array}{l}\text { DLS }( \pm S D) \text { Z-average } \\
\text { hydrodynamic } \\
\text { diameter, } \mathrm{nm}\end{array}$ & $\begin{array}{l}\text { TEM }( \pm \text { SD) } \\
\text { Average } \\
\text { diameter, } \mathrm{nm}\end{array}$ & $\begin{array}{l}\text { SEM Average } \\
\text { diameter, } \mathrm{nm}\end{array}$ & $\begin{array}{l}\text { Zeta } \\
\text { potential, } \\
\mathrm{mV}\end{array}$ \\
\hline 1.4 & 69.1 & 29.5 & 245.0 & $50.2( \pm 25.0)$ & $35.0( \pm 6.5)$ & $45.0( \pm 15.2)$ & 0.11 \\
\hline
\end{tabular}

\section{Results}

\section{Some colloidal chemical properties of the PNC}

The structure of the synthesized polymers was confirmed by the analysis of functional groups (Table 1), as well as NMR studies. The absence of the residual epoxy groups in the resulting product was confirmed by ${ }^{1} \mathrm{H}-\mathrm{NMR}$ spectroscopy (Bruker, Billerica, MA, US). ${ }^{1} \mathrm{H}$-NMR spectra were recorded on a Bruker Avance DPX 300 spectrometer at 300.13 MHz. The structure of the PNC in the DMSO- $\mathrm{d}^{3}$ was confirmed by ${ }^{1} \mathrm{H}$ NMR. In the ${ }^{1} \mathrm{H}-\mathrm{NMR}$ spectroscopy, the polymeric skeletal $\mathrm{CH}_{2}$ and $\mathrm{CH}$ were at $1.66 \mathrm{ppm}$ and $3.64 \mathrm{ppm}$, respectively; the GMA-graf-PEG fragment units demonstrated the following signals: $\mathrm{CH}_{3}-\mathrm{C}-\mathrm{C}(\mathrm{O})-\mathrm{O}-$ at $1.12 \mathrm{ppm}, \mathrm{CH}_{3}-\mathrm{O}-\mathrm{CH}_{2}-\mathrm{CH}_{2}-$ at $3.24 \mathrm{ppm}$, $\mathrm{CH}_{2}-\mathrm{CH}_{2}-\mathrm{O}$ - at $3.65 \mathrm{ppm}$; $-\mathrm{O}-\mathrm{CH}_{2}-\mathrm{CH}(\mathrm{OH})-$ at $4.67 \mathrm{ppm}$. The VEP fragment units demonstrated the following signals: $\left(\mathrm{CH}_{3}\right)_{3}-\mathrm{C}-\mathrm{O}-\mathrm{O}-$ at $1.18 \mathrm{ppm}$ and $-\mathrm{O}-\mathrm{O}\left(\mathrm{CH}_{3}\right)_{2}-$ at $1.36 \mathrm{ppm}$.

Table 1 shows the composition of the PNC and the size of the micelle-like colloidal structures, which were determined by various methods.

The diameter of the PNC-formed micelle-like structures was $30-45 \mathrm{~nm}$ according TEM and SEM data (Fig. 2). It is obvious from the intensity results of the DLS measurements (Fig. 3) that the values of the PNC size are in the range 20-200 nm with an average hydrodynamic diameter of $\sim 50 \mathrm{~nm}$. As expected, the hydrodynamic diameters from the DLS measurements were substantially larger compared to the dimensions determined by the TEM and SEM methods.

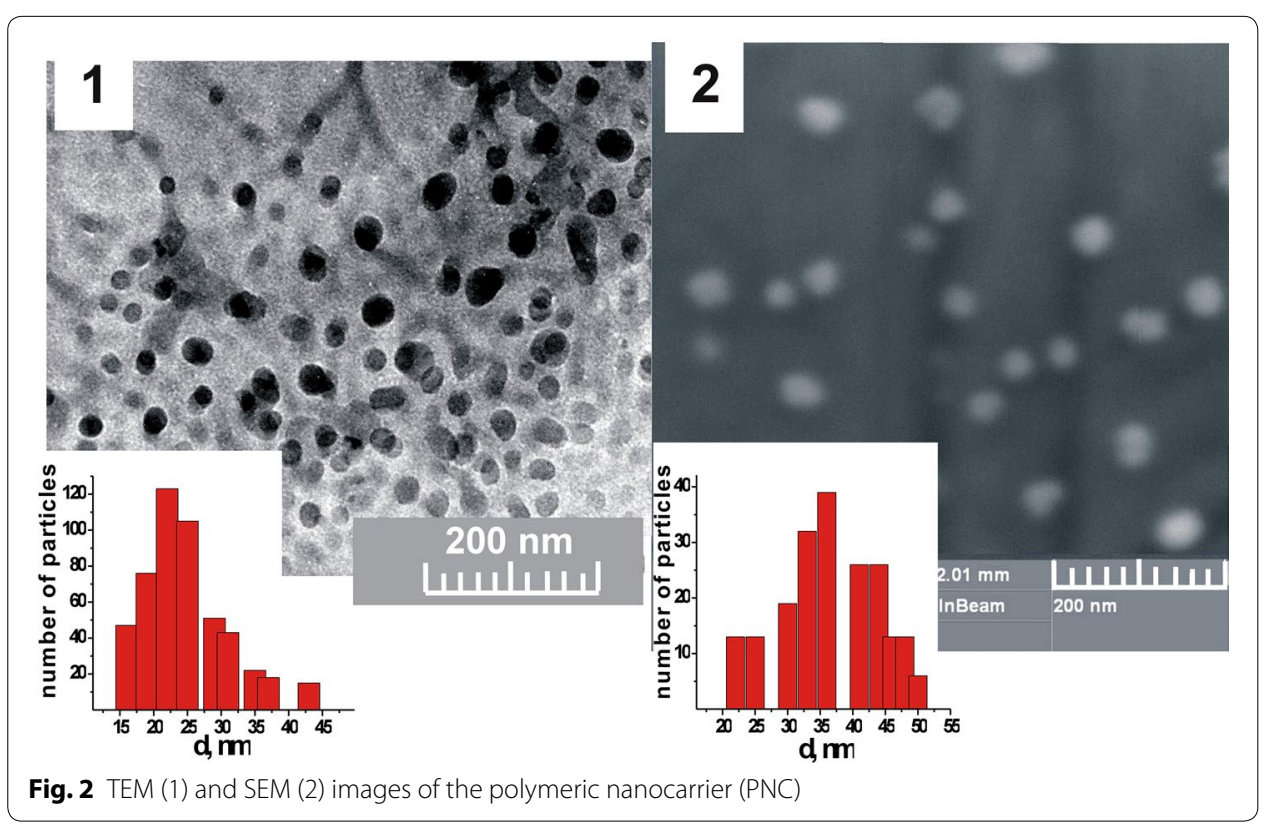




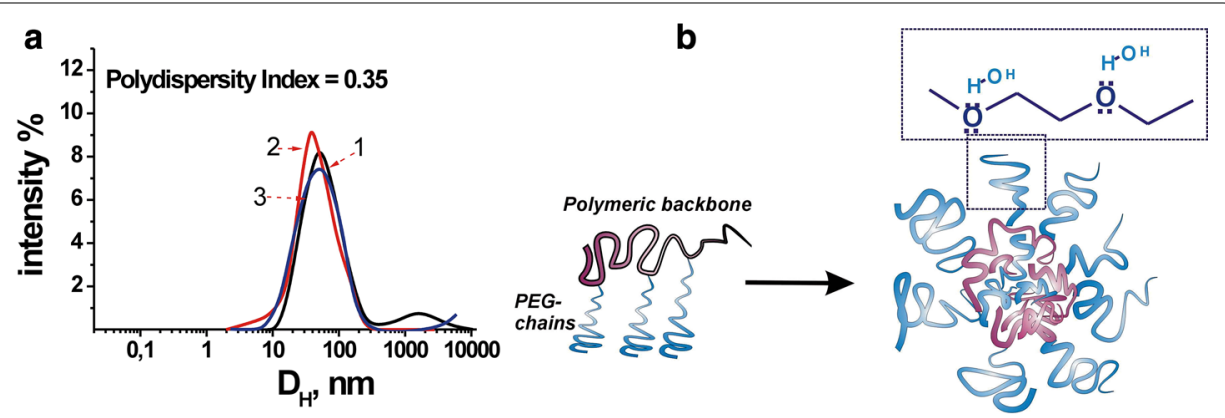

Fig. 3 Hydrodynamic diameter distributions of PNC formed by poly(VEP-Co-GMA)-graft-mPEG(750) (measurements made at intervals of $5 \mathrm{~min}$ : 1-at once, 2-in $5 \mathrm{~min}, 3$-in $10 \mathrm{~min}$ ) (a) and schematic structure of the micelles (b)

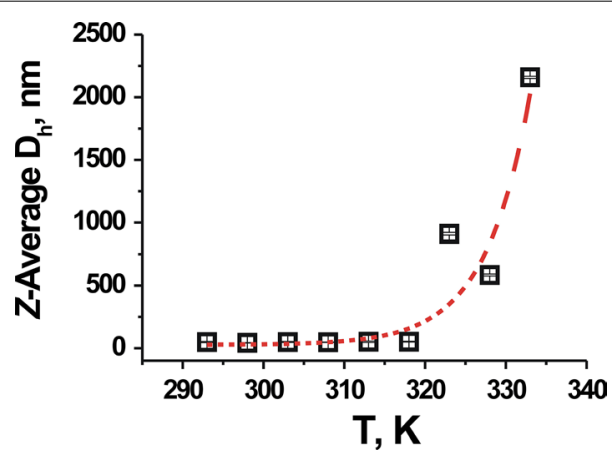

Fig. 4 The dependence of the hydrodynamic diameter of PNC formed by the poly(VEP-co-GMA)-graft-m PEG(750) on temperature

As seen in Fig. 4, it is apparent that the PNC size does not change in the temperature range of $293-318 \mathrm{~K}$, and that the dispersion is highly stable until $320 \mathrm{~K}$. Large agglomerates are formed at $333 \mathrm{~K}$ and sedimentation of the polymer aggregates is observed.

\section{Evaluation of PNC cytotoxicity in vitro}

PNC showed a weak toxic effect in MTT assay toward human leukemia (HL-60, Jurkat), hepatocellular (HepG2), colon (HCT116), and breast (MCF-7) tumor cell lines. PNC at the highest dose of $50 \mu \mathrm{M}$ inhibited HL-60 cell viability by $35.7 \%$ and the growth of Jurkat cells by $27.2 \%$. PNC at $5 \mu \mathrm{M}$ reduced cell growth of HepG2 cells by $19 \%$. At the $50 \mu \mathrm{M}$ dose of PNC, the growth inhibition of MCF-7 cells was $16 \%$ and HCT116 cells was $17 \%$ (Fig. 5).

The results of the Trypan blue exclusion assay of the cytotoxic action of PNC were similar to the results of the MTT assay. We determined $66.9 \%, 71.1 \%, 81.4 \%$ and $83.0 \%$ of viable HL-60, Jurkat, MCF-7 and HCT116 cells, respectively, after incubation with PNC at the $50 \mu \mathrm{M}$ dose for $72 \mathrm{~h}$ (Fig. 6).

\section{Physiological effects of the PNC}

Administration of PNC at the highest doses (1 $\mathrm{ml}$ for mice and $10 \mathrm{ml}$ for rats) induced a short suppression of the animals' physical activity due to the high volume of the injected drug. However, on the day after injection, there were no visible changes in the behavior 

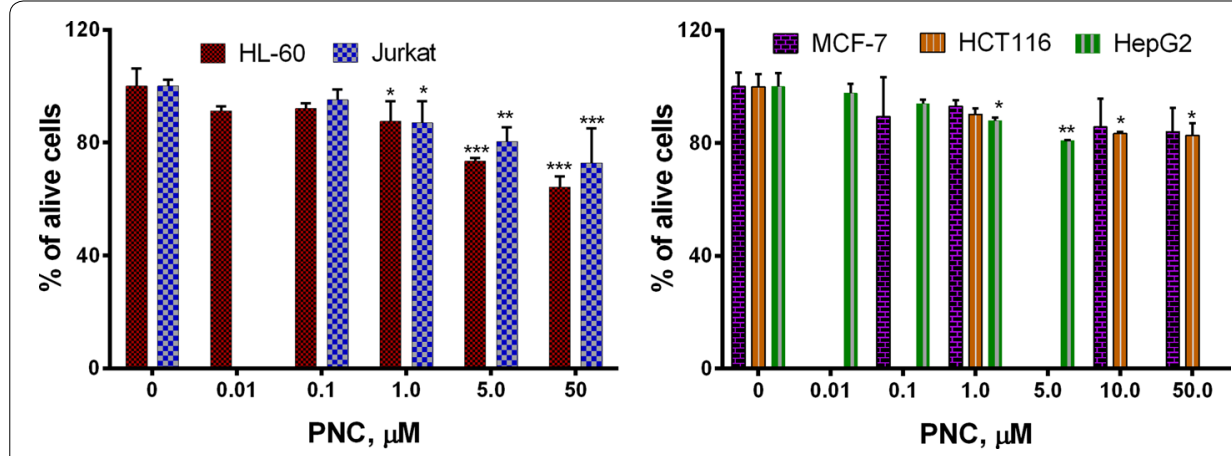

Fig. 5 Values of $I C_{50}$ determined by MTT assay after treatment for $72 \mathrm{~h}$ of these cell lines with the PNC: human leukemia (HL-60, Jurkat), hepatocellular (HepG2), colon (HCT116), and breast (MCF-7) tumor. ${ }^{*} P \leq 0.05$; ${ }^{* *} P \leq 0.01$ (difference compared with the non-treated control cells)
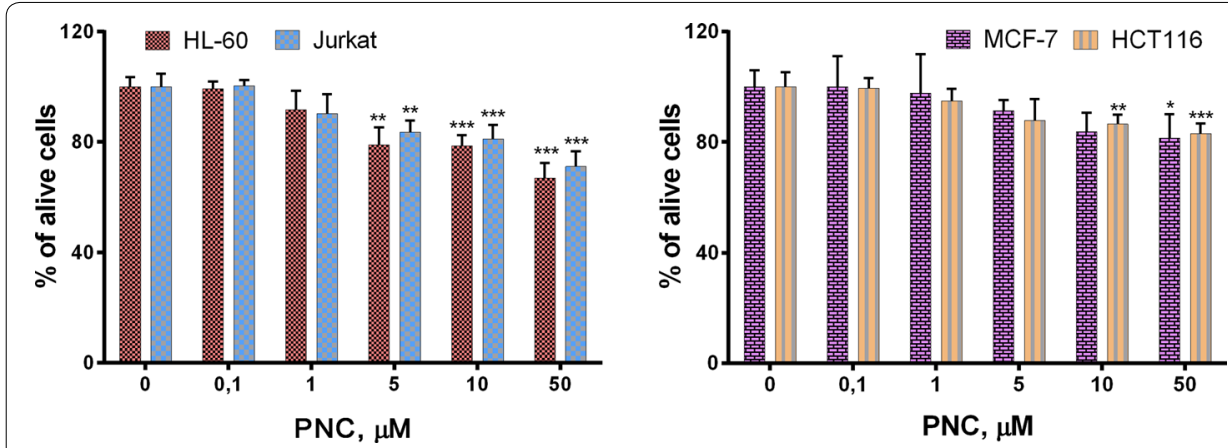

Fig. $6 \mathrm{LC}_{50}$ determined by Trypan blue exclusion test after treatment for $72 \mathrm{~h}$ of these cell lines with the PNC human leukemia (HL-60, Jurkat), colon (HCT116), and breast (MCF-7) tumor. ${ }^{*} P \leq 0.05 ;{ }^{* *} P \leq 0.01$ (difference compared with the non-treated control cells)

or physiological status of the animals. The same results were obtained by re-injecting the PNC in rats (10.0 $\mathrm{ml}$ dose that corresponded to $9.9 \mathrm{mg}$ of the PNC) and mice $(1.0 \mathrm{ml}$ dose that corresponded to $9.9 \mathrm{mg}$ of the PNC).

The body weight of animals treated with the PNC at the indicated doses did not differ substantially from the body weight measured prior to the administration of the PNC or at the end of the experiment (Fig. 7). The administered doses of the PNC did not have a pronounced toxic effect on the animals, and no animal died during the study (Table 2); all animals survived during IP administration of PNC.

\section{Biochemical indicators of the PNC toxicity in vivo}

The rats receiving the PNC demonstrated a significant $55.4 \%$ elevation in the activity of ALP on day 20 compared with control rats. The activity of other enzymes was close to the normal values with only minor deviations compared to the control group: GGT activity was decreased by $10 \%$, ALT by $18 \%$, LDH by $33 \%$, and creatine phosphokinase by $16 \%$, while $\alpha$-amylase activity was $17 \%$ higher. Concentrations of blood serum metabolites remained mostly unchanged during PNC injections for 20 days (Table 3). 

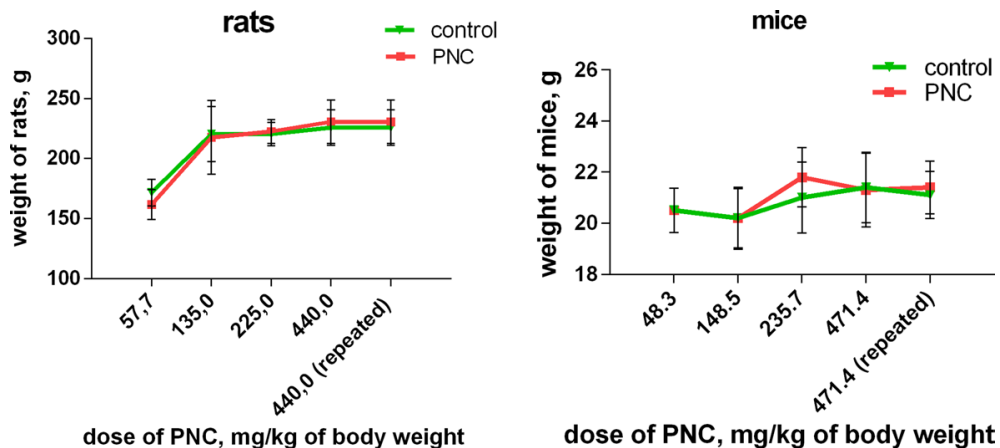

Fig. 7 The body weight of rats and mice treated with the PNC used at different doses (abscissa)

Table 2 The dosing of the polymeric nanocarrier (PNC) in the animals

\begin{tabular}{lll}
\hline Number of animals & $\begin{array}{l}\text { Dose of PNC, } \\
\mathbf{m g} / \mathbf{k g} \text { of body weight (ml of injected } \\
\text { solution) } \\
\text { Rats }\end{array}$ & $\begin{array}{l}\text { Dose of PNC, } \\
\mathbf{m g} / \mathbf{k g} \text { of body weight } \\
\text { (ml of injected solution) } \\
\text { Mice }\end{array}$ \\
\hline 6 & $57.7(1.0)$ & $48.3(0.1)$ \\
6 & $135(3.0)$ & $148.5(0.3)$ \\
6 & $225(5.0)$ & $235.7(0.5)$ \\
6 & $440(10.0)$ & $471.4(1.0)$ \\
6 (repeat injection) & $440(10.0)$ & $471.4(1.0)$ \\
\hline
\end{tabular}

Table 3 Concentration of metabolites and activity of enzymes in blood serum of rats treated with the polymeric nanocarrier (PNC) for 20 days

\begin{tabular}{|c|c|c|}
\hline & Control group & $\begin{array}{l}\text { PNC treated } \\
\text { group, } 20 \text { days }\end{array}$ \\
\hline Aspartate transaminase activity, $\mu$ kat/l & $0.648 \pm 0.045$ & $0.538 \pm 0.042^{*}$ \\
\hline Alanine transaminase activity, $\mu$ kat/l & $0.518 \pm 0.034$ & $0.425 \pm 0.041^{*}$ \\
\hline De Ritis coefficient & $1.25 \pm 0.05$ & $1.27 \pm 0.09$ \\
\hline$\gamma$-Glutamyltransferase activity, $\mu$ kat/l & $0.285 \pm 0.034$ & $0.255 \pm 0.21$ \\
\hline Creatine phosphokinase activity, $\mu$ kat/l & $2.31 \pm 0.02$ & $1.94 \pm 0.05^{*}$ \\
\hline Alkaline phosphatase activity, $\mu$ kat/l & $2.58 \pm 0.34$ & $4.01 \pm 0.28^{*}$ \\
\hline Lactate dehydrogenase activity, $\mu$ kat/l & $5.48 \pm 0.12$ & $3.69 \pm 0.07^{*}$ \\
\hline a-Amylase activity, $\mu$ kat/l & $2.01 \pm 0.09$ & $2.36 \pm 0.13$ \\
\hline Total protein, g/l & $76.5 \pm 3.5$ & $67.5 \pm 3.2$ \\
\hline Glucose, $\mathrm{mmol} / \mathrm{l}$ & $5.18 \pm 0.89$ & $6.09 \pm 0.78$ \\
\hline Urea, mmol// & $4.3 \pm 0.2$ & $5.1 \pm 0.3$ \\
\hline Creatinine, $\mu \mathrm{mol} / \mathrm{l}$ & $82.5 \pm 4.1$ & $70.7 \pm 2.9^{*}$ \\
\hline Calcium cation, mmol/l & $2.50 \pm 0.34$ & $3.22 \pm 0.51$ \\
\hline Iron cation, $\mu \mathrm{mol} / \mathrm{I}$ & $42.4 \pm 2.1$ & $42.5 \pm 3.2$ \\
\hline Sodium cation, $\mathrm{mmol} / \mathrm{l}$ & $127.5 \pm 14.5$ & $141.0 \pm 9.8$ \\
\hline Chloride anion, $\mathrm{mmol} / \mathrm{l}$ & $111.1 \pm 4.9$ & $119.8 \pm 12.8$ \\
\hline
\end{tabular}

*P $\leq 0.05$ 
The rats treated for 20 days with free PNC (i.e., lacking the conjugated anticancer compound) did not demonstrate significant changes in the concentration of total protein, urea, creatinine, or glucose in blood serum. The concentrations of calcium ions and iron also remained without substantial changes. Free PNC had no effect on the concentration of sodium cations and chlorine anions in blood serum. No nephrotoxic effect was recorded, highlighting the biosafety of this polymeric carrier used for delivery of anticancer drugs (Table 3).

Chemical components of the PNC were examined in urine and stool of rats treated with the PNC. The obtained results suggested that the PNC was metabolized, probably in liver tissue, and its clearance was under the control of the kidney. When estimating clearance of the PNC in daily urine and feces, it was found that rat feces contained $8-10 \%$ of the PNC in the native form, while urine contained $20 \%$ in the native form, with $15-20 \%$ as VEP and $13-25 \%$ as PEG. At the same time, liver tissue contained only traces of these products. Since all components of the PNC, namely, VEP, PEG, and PNC were present in the urine of the animals, the clearance of the degraded PNC likely occurred via filtration in the kidneys.

\section{Discussion}

The polymeric nanoparticles are perhaps the simplest form of soft materials used for biomedical applications due to their facile synthesis and wide applicability for biotechnology and for diagnostics and treatment in medicine. The best-known class of the polymeric nanomedicines is based on utilization of single polymeric chains either directly as the therapeutic agent, or as a modifying agent for a drug. The complexation of many drugs can significantly improve the biomedical and physicochemical characteristics of these drugs. A review article published in 2016 identified 51 FDA-approved nanomedicines and 77 products in clinical trials (Bobo et al. 2016). Since 1990, 12 PEGylated drugs have been approved in the USA and/or Europe (Turecek et al. 2016). There are already several FDA-approved polymeric nanomedicines including glatiramer acetate for multiple sclerosis and leuprolide acetate for advanced prostate cancer (Johnson et al. 1998; reviewed in Bobo et al. 2016).

In the process of PEGylation, PEG polymer chains can be attached to molecules, such as a drug, or to other polymers to make them less hydrophobic. PEGylation can significantly increase the biological half-life of a substance in plasma (Benbrook 2015). The PNC used in our study also contains PEG side chains. Although ethylene glycol can produce negative effects in the body such as metabolic acidosis, nephrotoxicity, and disturbed electrolyte balance, the polymeric form of ethylene glycol (PEG) demonstrates low toxicity, and a dose of $10 \mathrm{mg} / \mathrm{kg}$ of animal body weight is acceptable for treatment (Bunker 2012; Feng et al. 2015). Some of these groups that are available in the structure of the polymeric side chains might be subjected to metabolic transformation in liver (enzymatic cleavage with participation of alcohol dehydrogenase), while the remainder (20-50\%) might be excreted unchanged in the urine (Bunker 2012; Feng et al. 2015).

PNC used might produce peroxide groups $(-\mathrm{O}-\mathrm{O}-)$ in the treated animals (Riabtseva et al. 2012). Previously, we have shown high thermal stability of the ditertiary peroxide groups with the activation energy of the peroxide group decomposition equal to $110 \mathrm{~kJ} / \mathrm{mole}$ (Riabtseva et al. 2012). It should be noted that the content of the peroxide 
groups in the structure of the used PNC did not exceed 1\% (Zaichenko et al. 1997, see Table 1). Besides, if these groups were not stable, we would expect changes in the enzymatic activities in the experimental animals. However, we did not observe such changes in blood serum of the treated animals (Kobylinska et al. 2015, 2016).

Liver contained only traces of these products that suggests very low or no accumulation of the PNC products in this organ. The feces of treated animals contained low concentration (8-10\%) of PNC. The urine had twice higher PNC in native form and contained the fragments of the injected PNC. Since all components of the PNC (VEP, PEG, and $\mathrm{PNC}$ ) were detected in the urine of treated animals, one can suggest that the clearance of the degraded PNC took place via kidney filtration.

In previous studies, we demonstrated an enhanced antineoplastic activity of the anticancer substances in mammalian tumor cells, when these substances were delivered by the developed PNC (Kobylinska et al. 2015, 2016). In this study, even at the highest concentrations these PNCs (the dose equivalent to the amount of polymer used in a complex with the anticancer drug) had a very weak toxic effect on cell viability. The data of this investigation together with the results of studying general toxicity of the free PNC (Kobylinska et al. 2015, 2016) suggest the biocompatibility of the PNC and confirm its potential for use as a drug delivery system (Heffeter et al. 2013; Senkiv et al. 2014).

\section{Conclusion}

In this study, we demonstrated that the synthesized comb-like PEG-containing PNC possesses weak toxic effects toward human leukemia cells (HL-60 and Jurkat lines), as well as toward hepatocellular (HepG2), colon (HCT116), and breast (MCF-7) tumor cell lines. In addition, the PNC has no toxic effect in laboratory white mice (used at a dose of $470 \mathrm{mg} / \mathrm{kg}$ body mass, volume $1 \mathrm{ml}$ ) and laboratory Wistar rats (used a dose of $440 \mathrm{mg}$ / $\mathrm{kg}$ body mass, volume $10 \mathrm{ml}$ ). Taking into account the obtained results, the PNC we developed and studied can be qualified as a compound of grade 4 toxicity (low toxicity substance). The reduced toxicity of this PNC in combination with its improved bioavailability and previously detected capability to enhance cytotoxicity toward tumor cells in vitro and tumor treatment effects in mice suggest great potential for its safe use as a drug delivery platform for treatment of various diseases, especially cancer.

\footnotetext{
Abbreviations

ALP: alkaline phosphatase; ALT: alanine transaminase; AST: aspartate transaminase; DMSO: dimethyl sulfoxide; GGT: $\gamma$-glutamyltransferase; GMA: glycidyl methacrylate; LDH: lactate dehydrogenase; PEG: polyethylene glycol; PNC: polymeric nanocarrier; SEM: scanning electron microscopy; TEM: transmission electron microscopy; VEP: 5-(tert-butylperoxy)-5-methylhex-1-en-3-yne.
}

\section{Authors' contributions}

LK and SGV contributed to the conception of the study, the preparation of the manuscript text, and the interpretation of the results. NM, AR and AZ were responsible for synthesis and characterization of the polymeric nanocarrier and water systems. LK, IP, and IK conducted the research work for testing the toxicity of the polymeric nanocarrier with laboratory mice and rats. NF conducted testing of the cytotoxicity using MTT and Trypan blue exclusion assays. LK studied the biochemical indicators of the polymeric nanocarrier toxicity in vivo. LK, AZ, RS and SGV reviewed and corrected the final manuscript. All authors read and approved the final manuscript.

\section{Author details}

1 Danylo Halytsky Lviv National Medical University, Pekarska str., 69a, Lviv 79010, Ukraine. ${ }^{2}$ State Scientific-Research Control Institute of Veterinary Medicinal Products and Feed Additives, Donetska str., 11, Lviv 79019, Ukraine. ${ }^{3}$ Institute of Cell Biology, Drahomanov str., 14/16, Lviv 79005, Ukraine. ${ }^{4}$ Lviv Polytechnic National University, S. Bandera str., 12, Lviv 79013, Ukraine. ${ }^{5}$ International Research and Innovation in Medicine Program, Cedars-Sinai Medical Center, 6500 Wilshire Blvd., Ste. 2102, Los Angeles, CA 90048-5502, USA. 


\section{Acknowledgements}

The study was supported by Cedars-Sinai Medical Center's International Research and Innovation in Medicine Program, the Association for Regional Cooperation in the Fields of Health, Science and Technology (RECOOP HST Association) and the participating Cedars-RECOOP Research Centers (CRRC).

\section{Competing interests}

All authors declare that no support was received from any organization for the submitted work; in the previous 3 years, the authors have had no financial relationships with any organizations that might have an interest in the submitted work; the authors have no other relationships or activities that could influence the submitted work.

\section{Availability of data and materials}

All data generated or analyzed during this study are included in this published article [and its supplementary information on file].

\section{Bio-ethics committee approval}

In this study, the research protocols and the experimental procedures using animals were approved by the Ethical Committee of Danylo Halytsky Lviv National Medical University (Ukraine) on April 18, 2016 in Protocol N4.

http://zakon.rada.gov.ua/cgi-bin/laws/main.cgi?nreg=z0053-10/

http://zakon2.rada.gov.ua/laws/show/994_137/

http://zakon4.rada.gov.ua/laws/show/3447-15/

\section{Consent for publication}

Not applicable.

\section{Funding}

This work was partially supported Danylo Halytsky Lviv National Medical University (LK), State Scientific-Research Control Institute of Veterinary Medicinal Products and Feed Additives (IP, IK), National University "Lvivska Polytechnica" (NM, OP, AZ).

\section{Publisher's Note}

Springer Nature remains neutral with regard to jurisdictional claims in published maps and institutional affiliations.

Received: 27 July 2018 Accepted: 12 December 2018

Published online: 20 December 2018

\section{References}

Benbrook DM. Biotechnology and biopharmaceuticals: transforming proteins and genes into drugs, 2nd edition. Clin Infect Dis. 2015;60(2):331-2.

Bobo D, Robinson K, Islam J, et al. Nanoparticle-based medicines: a review of FDA-approved materials and clinical trials to date. Pharm Res. 2016;33:2373-87. https://doi.org/10.1007/s11095-016-1958-5.

Bunker A. Poly(ethylene glycol) in drug delivery, why does it work, and can we do better? All atom molecular dynamics simulation provides some answers. Phys Procedia. 2012;34:24-33. https://doi.org/10.1016/j.phpro.2012.05.004.

Diehl K, Hull R, Morton D, et al. A good practice guide to the administration of substances and removal of blood, including routes and volumes. J Appl Toxicol. 2001;21:15-23. https://doi.org/10.1002/jat.727.

Faqi AS. A comprehensive guide to toxicology in preclinical drug development. San Diego: Elsevier; 2013.

Faqi AS. A comprehensive guide to toxicology in nonclinical drug development. 2nd ed. London: Elsevier; 2017.

Feng R, Zhu W, Teng F, et al. Poly(ethylene glycol) amphiphilic copolymer for anticancer drugs delivery. Anticancer Agents Med Chem. 2015;15(2):176-88.

Han J, Zhao D, Li D, et al. Polymer-based nanomaterials and applications for vaccines and drugs. Polymers. 2018;10:31. https://doi.org/10.3390/polym10010031.

Heffeter P, Riabtseva A, Senkiv Y, et al. Nanoformulation improves activity of the (pre)clinical anticancer ruthenium complex KP1019. J Biomed Nanotechnol. 2013;9:1-8. https://doi.org/10.4103/0976-500X.81895.

Igarashi E. Factors affecting toxicity and efficacy of polymeric nanomedicines. Toxicol Appl Pharmacol. 2008;229:121-34. https://doi.org/10.1016/j.taap.2008.02.007

Johnson KP, Brooks BR, Cohen JA, Ford CC, Goldstein J, Lisak RP, et al. Extended use of glatiramer acetate (Copaxone) is well tolerated and maintains its clinical effect on multiple sclerosis relapse rate and degree of disability. Neurology. 1998;50(3):701-8.

Kobylinska LI, Havrylyuk DY, Ryabtseva AO, et al. Biochemical indicators of hepatotoxicity in blood serum of rats under the effect of novel 4-thiazolidinone derivatives and doxorubicin and their complexes with polyethyleneglycolcontaining nanoscale polymeric carrier. Ukr Biochem J. 2015;87(2):122-32.

Kobylinska LI, Havrylyuk DYa, Mitina NE, et al. Biochemical indicators of nephrotoxicity in blood serum of rats treated with novel 4-thiazolidinone derivatives or their complexes with polyethyleneglycol-containing nanoscale polymeric carrier. Ukr Biochem J. 2016;88(1):51-60. https://doi.org/10.15407/ubj88.01.051.

Li Y, Ogris M, Wagner E, Pelisek J, Ruffer M. Nanoparticles bearing polyethyleneglycol-coupled transferring as gene carriers: preparation and in vitro evaluation. Int J Pharm. 2003;259:93-101.

Nath Roy D, Goswami R, Pal A. Nanomaterial and toxicity: what can proteomics tell us about the nanotoxicology? Xenobiotica. 2017;47(7):632-43. https://doi.org/10.1080/00498254.2016.1205762. 
Pinto Reis C, Neufeld R, Ribeiro A, Veiga F. Nanoencapsulation I. Methods for preparation of drug-loaded polymeric nanoparticles. Nanomedicine. 2006;2:8-21. https://doi.org/10.1016/j.nano.2005.12.003.

Riabtseva A, Mitina N, Boiko N, et al. Structural and colloidal-chemical characteristics of nanosized drug delivery systems based on pegylated comb-like carriers. Chem Chem Technol. 2012;6(3):291-5.

Senkiv Y, Riabtseva A, Heffeter P, et al. Enhanced anticancer activity and circumvention of resistance mechanisms by novel polymeric/phospholipidic nanocarriers of doxorubicin. J Biomed Nanotechnol. 2014;10(7):1369-81.

Steyermark Al. Quantitative organic microanalysis. New-York: Academic Press; 1961.

Turecek PL, Bossard MJ, Schoetens F, Ivens IA. PEGylation of biopharmaceuticals: a review of chemistry and nonclinical safety information of approved drugs. J Pharm Sci. 2016;105:460-75. https://doi.org/10.1016/j.xphs.2015.11.015.

Voronov SA, Kiselyov EM, Minko SS, Budishevska OG, Roiter YV. Structure and reactivity of peroxide monomers. J Polym Sci Pol Chem. 1996;34(12):2507-11. https://doi.org/10.1002/(SICI)1099-0518(19960915)34:12\%3c2507:AID-POLA2 4\%3e3.0.CO;2-B.

Wang L, Du J, Zhou Y, Wang Y. Safety of nanosuspensions in drug delivery. Nanomedicine. 2017;13(2):455-69. https://doi. org/10.1016/j.nano.2016.08.007.

Zaichenko A, Voronov S, Shevchuk O, et al. Kinetic features and molecular-weight characteristics of terpolymerization products of the systems based on vinyl acetate and 2-tert-butyl-peroxy-2-methyl-5-hexene-3-yne. J Appl Polym Sci. 1997;67:1061-6.

Zhang J, Li S, Li X. Polymeric nano-assemblies as emerging delivery carriers for therapeutic applications: a review of recent patents. Recent Pat Nanotechnol. 2009;3(3):225-31.

Ready to submit your research? Choose BMC and benefit from:

- fast, convenient online submission

- thorough peer review by experienced researchers in your field

- rapid publication on acceptance

- support for research data, including large and complex data types

- gold Open Access which fosters wider collaboration and increased citations

- maximum visibility for your research: over 100M website views per year

At BMC, research is always in progress.

Learn more biomedcentral.com/submissions 